\title{
Interdependence of mining industry and industrial sectors in Slovakia
}

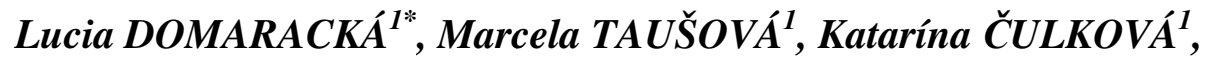 \\ Henrieta PAVOLOVÁ, Tomáš BAKALÁR ${ }^{1}$, Andrea SEŇOVÁ, \\ Mária SHEJBALOVÁ - MUCHOVÁ ${ }^{1}$, Katarína TEPLICKÁ ${ }^{1}$ and Barbara KOWAL ${ }^{2}$
}

Authors' affiliations and addresses:

${ }^{1}$ Technical University Košice, Letná 9, 04001

Košice, Slovakia

e-mail: lucia.domaracka@tuke.sk

e-mail:marcela.tausova@tuke.sk

e-mail: katarina.culkova@tuke.sk

${ }^{2}$ AGH University of Science and Technology in Kraków

*Correspondence:

Lucia Domaracká, Technical University Košice,

Letná 9, 04001 Košice, Slovakia

e-mail: lucia.domaracka@tuke.sk

Funding information:

VEGA - Grant No 1/0515/18

EIT LIMBRA - No 18197

How to cite this article:

Domaracká, L., Taušová, M., Čulková, K.

Pavolová, H., Bakalár, T., Seňová, A., Shejbalová

- Muchová, M., Teplická, K. and Kowal, B. (2020). Interdependence of mining industry and industrial sectors in Slovakia. Acta Montanistica Slovaca, Volume 25 (4), 494-503

DOI:

https://doi.org/10.46544/AMS.v25i4.05

\begin{abstract}
Due to globalization, all industrial sectors are mutually connected, which means that the sectors are part of the global economy, influenced by a similar trend. Mining relates to various industrial sectors. The base of mineral raw materials provides in the frame of certain regions the value that is possible to evaluate with optimal use complexly, and by this way profit for the owner, state and mining company, as well as single region is created. The goal of the presented contribution is to search for a position of raw material using in industries and its trend from the view of growth rate, in connection to the growth of other industries with the aim to provide long-term prosperity and contribution of industries to the national economy. Research had been done through growth rate of sales and revenues and one-way analysis of sales trend in analyzed period 2009-2018. The research is supported by initial decline analysis, orientated to the evaluation of positive and negatives of raw material using generally. According to the internal analysis, there are selected sectors directly connected to the mining industry. The results show there is the stable or improving character of the mining industry, which is very similar to industrial production, having influence with other industrial sectors. There is a recorded trend in the growth of individual industries, which varies significantly. The results of the contribution are useful in providing long-term prosperity and contribution of industries to the national economy, providing sustainable economic growth. The contribution is limited to the evaluation of industries growth from the view of sales and revenues, and future research can be extended to the evaluation from the view of market share, etc. Future research can also be extended to other macro-economic indicators, influencing the competitiveness of the mining industry and its sustainable tendency.
\end{abstract}

\section{Keywords}

mining industry, economic growth, growth rate of sales, raw materials, Slovakia. 


\section{Introduction}

The human population trend these days is more and more connected to natural, technical, or technological development, influenced by the use of raw materials (Šimák, 2006). Due to globalization, all industrial sectors are mutually connected, which means that the sectors are part of the global economy, influenced by a similar trend. In this connection, industrial sectors present certain complexity in the development of the individual sector (Kot \& Măcriş 2014). Industrial sectors, including raw materialsuse, need to meet and manage pressure from the side of global competition, which requires following up sustainable development of industries (Diabat et al., 2014). Moreover, as a base for other industries, raw material use is a task connected to providing energetic and raw material security of countries and regions (Mačanga, 2014). Such security can be viewed from various points, for example, as stable availability of raw materials, providing for economic growth with the lowest possible cost or price volatility (Alhajji, 2007). To provide economic growth,it is necessary to regard and evaluate risks in various industrial activities at the level of business activities management (Pačaiová \& Blišt’an, 2010). This fact would enable creating a new solution and improving present processes to achieve long-term determined goals and satisfaction of society.

Therefore, the presented contribution aims to search the position of raw material use and its trend from the view of growth rate, in connection to the growth of other industries. The aim is also to provide long-term prosperity and contribution of industries to the national economy. To provide such long-term development and growth, it is necessary to focus on creating a positive growth rate, providing a decrease of individual sectors decline (Ishchenko, 2013).

\section{State of the problem}

Mining relates to various industrial sectors. Especially, mining and metallurgy present one of the most important sectors in some countries, presenting a contribution to the state economy (Manová et al., 2018). As rare earth resources are indispensable raw materials for modern society, they have become strategic global reserve resources. From the view of sustainability, industries need to develop novel and effective materials by proper use of raw materials (Katare \& Madurwar, 2020). Sustainable development is presently affected by the socio-economic impacts of environmental issues, which demands effective use of materials and avoiding waste production (Jokar \& Mokhtar, 2018). For these reasons, the study of Ferella et al. (2019) tries to implement recycling strategies towards circular economy models, increasing effective raw materials (RM) use in industries. Liang et al. (2018) establish an innovative evaluation index system for the sustainable development of China's rare earth resources from six main aspects: economic development, social progress, environmental protection, technological innovation, rare earth development and utilization, and rare earth protection in which the indicators are assessed using an entropy method.

A further connection between the mining industry and other industrial sectors is robotics applications in the raw materials sector, which becomes increasingly common due to their many perceived benefits, including improved productivity, decreased production costs, better operational efficiency, increased safety, reduced waste production, and, ultimately, more value creation (Lopes et al., 2018; Marshall et al., 2016). Industries could procure an increased quantity of rawmaterial while increasing economic effectiveness and quality (Shetty and Raghavendra, 2018). Ivanova et al. (2018) confirmed that metallurgical, machine, building industry, as well as extractive industry and construction are connected to the rawmaterial chain and integrated sales channels, which could contribute to the gradual recovery of the enterprises from a decline and their development, which, in turn, increases the investment competitiveness (Dul'ová et al., 2017).

The base of mineral raw materials provides, in the frame of certain regions, the value that is possible to evaluate with optimal use complexly, and,in this way, profit for the owner, state, and mining company, as well as single region is created (Ciruelos \& Duchene, 1983). Profit for the state can be the possible reasonable and rational use of deposits, as defined in the legislation of raw materials use. Profit for mining organizations can be the profit creation when providing sustainability. Profit for the region is in the sense of administration creation of wealth for region's inhabitants that is viewed through the support of new working posts, support of regional taxes creation, or taxes, orientated directly to the region, and availability of raw material sources that are necessary for region's development. The owner of deposits of raw materials in conditions of Slovakia is the state, but the state does not have a definite obligation to economically evaluate all recorded deposits of raw materials (Zuberec et al., 2005; Blišt’an, 2015). The sector of mining and processing of raw materials in Slovakia is fully privatized, and the state, as the owner of raw materials deposits, creates, in accordance with available legislation space and conditions for business, subjects for effective use of raw materials. The principle of freedom in business when observing the determined rules also applies in raw material use (Šimková et al., 2019).

It means that problems of evaluation of raw material deposits are very actual and necessary for the business sector, as well as for the private sector (Cehlár \& Maras, 2001). In developed market economies, evaluation of reserved deposits is considered one of the most complex and most important activities while finding and 
researching any raw material deposit. Market estimations of prices of deposits and raw material sources in Slovakia can exist only due to Act No.18/1996 Coll. as amended on prices. However, it would not be advisable to prescribe detailed pricing procedures for price determination for a wide range of evaluation needs for real estate variants. Current mining practice shows that market estimations use for the evaluation of non-monetary deposits to equity of the company, mainly capital debts and warranty coverage.

\section{Methodology and data}

The research of the interdependence between the mining industry and industrial sectors was done by the growth rate based on sales and revenues and one-way analysis of the trend of sales in percentage expression. The analyzed period is 2009-2018. The growth index can be evaluated as follows (Pacáková et al., 2009):

The growth rate of sales $(g)$ :

$$
g=\left(\Delta S / S_{o}\right) * 100 \%
$$

where: $\Delta S$ - change of sales in time

$S_{o}$ - sales in time zero

The growth was searched as:

- Internal growth - through increasing of production volume, increasing of export, quality of production improving, etc.

- External growth - through the strengthening of the industry position in the national economy.

On the other hand, the growth can be:

- $\quad$ neither too rapid (such a situation could cause debts increasing, connected with the instability of the sector),

- $\quad$ neither too slow (such a situation could cause overtaking by competition).

The intensity and stability of the growth in individual sectors had been analyzed through simple linear regression, while there is searched the rate between the dependent index Y and independent index X. In our case, dependent index Y means an annual change of the sales at the level of individual sectors, expressed in percentage expression; the independent index is X, both indexes followed during 2010-2018. The basic simple regression model has the following formula:

$$
y_{i}=f\left(x_{i}\right)+\epsilon_{i},
$$

where:

$$
\begin{array}{ll}
y_{i} & i \text { - observed value of explained index, } \\
x_{i} & i \text { - value of explained index, } \\
i & =1,2, \ldots, n \\
n & \text { number of observations } \\
\epsilon_{i} & \text { random (residual) element of } i \text { - observation (used to be called also as random error), }
\end{array}
$$

Function fis called aregression function. The regression function presents a deterministic element. In case the regression function is linear, it means having the shape of the regression as a straight line; we speak about simple linear regression.

$$
y_{i}=\beta_{0}+\beta_{1} x_{i}+\epsilon_{i}
$$

where:

$\beta_{0}$ model parameter, so-called localization constant, expressing what value index $\mathrm{Y}$ will have in case $\mathrm{X}$ will equal zero

$\beta_{1}$ model parameter, so-called regression coefficient, expressing the slope of the regression line. The parameter informs how many units will Y change averagely, in case $\mathrm{X}$ would change by 1 unit

$\beta_{1}>\quad$ positive dependence

$\beta_{1}<\quad$ negative dependence

The point estimation of regression straight line is following the balance line:

$$
\hat{y}_{i}=b_{0}+b_{i} x_{i}
$$


where:

$\widehat{\boldsymbol{y}}_{\boldsymbol{i}}$ - i- balance value of dependent index Y

$x_{i}$ - value of independent index $\mathrm{X}$ for observation " $i$ "

$b_{0}$-point estimation of parameter $\beta_{0}$

$b_{1}$ - point estimation of parameter $\beta_{1}$

The estimated regression line's quality was evaluated through the coefficient of determination $r_{y x}{ }^{2}$, which expresses the regression line's rate, describing the relation between the dependent and independent index. The values are moving in the interval: 0,1 . The coefficient of determination gives $\%$ explained variability of the dependent index, and it is defined as a rate of the variability of the dependent index, explained by estimated regression equation and total variability of the dependent index.

$$
r^{2}=\frac{\sum_{i}\left(\widehat{y}_{i}-\bar{y}\right)^{2}}{\sum_{i}\left(y_{i}-\bar{y}\right)^{2}}
$$

where:

$\hat{y}_{i} \quad i$ - balance value of dependent index $\mathrm{Y}$

$\overline{\boldsymbol{y}} \quad$ arithmetical average of dependent index $\mathrm{Y}$

There is a claim to provide sustainable growth and development through increasing sales and capital invested in the business (Anyakoha, 2018).

Before a single evaluation of the growth rate in the sectors and their possible decline, initial analysis, oriented to the evaluation of positives and negatives of raw material using generally, followed up by evaluation of mining industry was done in Slovakian conditions. The data from the mining industry's initial analysis are summarized in Table 1,presenting the RM sector's influence on other economies.

Tab.1. Data for the research from initial analysis of mining industry

\begin{tabular}{l|l}
\hline Positives & Negatives \\
\hline $\begin{array}{l}\text { Resistance against pricefluctuation in } \\
\text { leadingcompanies }\end{array}$ & High debt level, especially between slateoil companies \\
\hline $\begin{array}{l}\text { Expected high demand inthe future, connected to the } \\
\text { high worldwide growth ofconsumption }\end{array}$ & High volatility of oil prices \\
\hline Effort of gas companies tosimplify the production & Surplus of oil production \\
\hline $\begin{array}{l}\text { Implementation of anagreement aboutproduction } \\
\text { freezing }\end{array}$ & $\begin{array}{l}\text { Redundant capacity of services in several oil andgas } \\
\text { companies }\end{array}$ \\
\hline \multicolumn{1}{c}{ Source: COFACE handbook, 2018, p.228 } \\
\hline
\end{tabular}
Source: COFACE handbook, 2018, p. 228

During the evaluation of industries' interdependence, the statistical classification of economic activities SK NACE Rev.2 was used. According to the internal analysis of selected keywords from the mining industry (www1), the selected sectors directly connected to the mining industry were selected by comparing the intensity of individual sectors' findings. The results of the analysis of the keywords were processed in the form of a bubble graph that represents the found terms grouped according to the keywords, where:

- $\quad \mathrm{x}$-axis represents the terms in an analytical way and

- $\quad y$-axis represents the sector.

The grouping was done based on keywords to which the terms are connected to. The volume of the bubblesrepresents the multiplicity of the given term (keyword).

\section{Results}

The trend of mining sales, compared with other industries, is illustrated by Table 2 and Figure 1.

Tab.2. The trend of sales in industrial sectors (2010-2018) in \%

\begin{tabular}{|c|c|c|c|c|c|c|c|c|c|}
\hline & 2018 & 2017 & 2016 & 2015 & 2014 & 2013 & 2012 & 2011 & 2010 \\
\hline Industry together & 114.73 & 106.83 & 101.43 & 99.99 & 71.1 & 86.88 & 95.27 & 106.18 & 74.81 \\
\hline $\begin{array}{l}\text { Mining and } \\
\text { extraction }\end{array}$ & 103.88 & 94.87 & 93.15 & 108.78 & 85.44 & 84.59 & 87.33 & 107.96 & 94.62 \\
\hline $\begin{array}{l}\text { industrial } \\
\text { production }\end{array}$ & 106.49 & 106.44 & 100.93 & 99.35 & 84.59 & 91.78 & 90.13 & 84.27 & 72.56 \\
\hline $\begin{array}{l}\text { production of coke } \\
\text { and refined } \\
\text { petroleum }\end{array}$ & 94.61 & 86.71 & 75.05 & 99.96 & 101.53 & 127.42 & 126.87 & 129.32 & 66.59 \\
\hline
\end{tabular}




\begin{tabular}{|c|c|c|c|c|c|c|c|c|c|}
\hline products & & & & & & & & & \\
\hline $\begin{array}{l}\text { production of } \\
\text { chemicals and } \\
\text { chemical products }\end{array}$ & 95.05 & 97.93 & 90.28 & 100.84 & 96.71 & 103.42 & 109.96 & 129.09 & 88.83 \\
\hline $\begin{array}{l}\text { production of } \\
\text { products from } \\
\text { plastics and rubber }\end{array}$ & 115.53 & 110.33 & 106.18 & 99.86 & 87.58 & 89.39 & 97.51 & 86.41 & 73.13 \\
\hline $\begin{array}{l}\text { production of } \\
\text { metals and metal } \\
\text { construction }\end{array}$ & 126.84 & 114.11 & 99.87 & 99.43 & 105.71 & 86.61 & 88.02 & 85.68 & 77.97 \\
\hline $\begin{array}{l}\text { production of } \\
\text { computer, } \\
\text { electronic and } \\
\text { optical products }\end{array}$ & 78.63 & 93.39 & 100.31 & 91.08 & 97.75 & 99.78 & 106.63 & 102.18 & 137.74 \\
\hline $\begin{array}{l}\text { production of } \\
\text { electric equipment }\end{array}$ & 110.14 & 108.66 & 104.44 & 100.01 & 93.01 & 85.61 & 74.01 & 72.94 & 61.28 \\
\hline $\begin{array}{l}\text { production of } \\
\text { machinery }\end{array}$ & 125.8 & 118.64 & 105.37 & 100.11 & 91.99 & 87.34 & 74.46 & 70.66 & 58.02 \\
\hline $\begin{array}{l}\text { production of } \\
\text { transport } \\
\text { machinery }\end{array}$ & 123.69 & 98.94 & 106.49 & 100.49 & 87.59 & 87.13 & 81.91 & 68.32 & 52.74 \\
\hline $\begin{array}{l}\text { other production, } \\
\text { repairing, and } \\
\text { installation of } \\
\text { machinery }\end{array}$ & 106.37 & 104.81 & 97.18 & 100.03 & 93.26 & 84.06 & 97.06 & 85.48 & 80 \\
\hline $\begin{array}{l}\text { supply of } \\
\text { electricity, gas, } \\
\text { steam, and cold air }\end{array}$ & 114.26 & 109.8 & 100.45 & 99.96 & 97.33 & 112.03 & 133.04 & 107.38 & 87.45 \\
\hline $\begin{array}{l}\text { supply of water, } \\
\text { cleaning of } \\
\text { wastewater, and } \\
\text { waste disposal } \\
\end{array}$ & 118.13 & 107.04 & 105.6 & 99.16 & 91.82 & 95.83 & 96.37 & 89.91 & 92.34 \\
\hline
\end{tabular}

Source: processed according to data from (www2)

The trend in the mining sector is very similar to industrial production, the best situation was in 2015, with the highest growth rate, and the lowest rate was in 2013. All other sectors, using raw materials, had a miscellaneous trend of sales development. In 2018 the most positive trend of development was registered in the production of metals and metal construction. The mining sector showed a smooth increase, although not the highest in its history. In the mining industry, it is also important to follow up the development of sales that is illustrated during the analyzed period 1990-2015 in Figure 2. The values of the index are calculated by the current exchange rate.

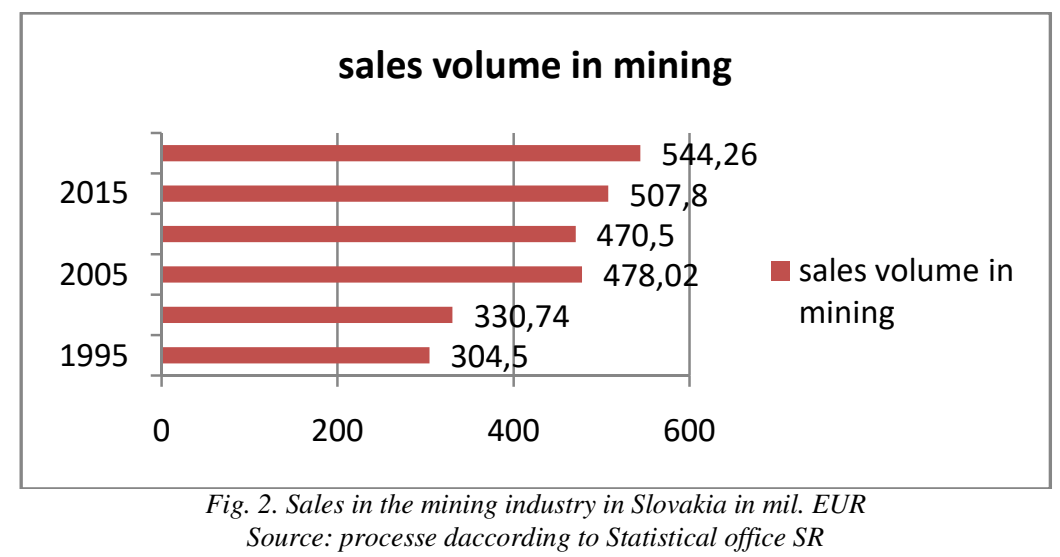

The graphical representation of the sales volume from mining in the years 1995 - 2018 (Fig. 2) clearly shows that this was characterized by a fluctuating trend with an average annual sale of 439.3 mils. $€$ per year. A small drop in sales was recorded in 2010, but in the following years sales increased. In 2018 sales in the mining industry were approximately 544 mils. $€$. In general, it could be stated that mining increased in 2018 compared to 1995 by 239.76 mil. $€$ per year, while the average year-on-year index in the analyzed period showed a level of 47.95. In general, it could also be stated that mining increased in 2018 compared to 1995 by 239.76 mils. $€$ per year. Due to the mentioned, it is very important to monitor the development tendencies of sales from mining from the point of view of sales. 


\section{One-way analysis of sales trend by industrial sectors}

The trend of sales in particular industrial sectors in 2009-2018is presented in Figure 3. The trend in the change of individual industries varies significantly, some industries recorded significant growth in the first years of monitoring (blue square), for example, in the case of production of computer, electronic and optical product, and, in recent years of monitoring,there is a decline with a trend of change of 75\% in the mentioned branch. Some industries underwent variable development over the years (growth alternated with declining sales) as in the case of mining and extraction, Industry together, production of coke and refined petroleum product. However, the results of the analysis also point to sectors with stable long-term growth, as in the case of industrial production, production of machinery, etc.

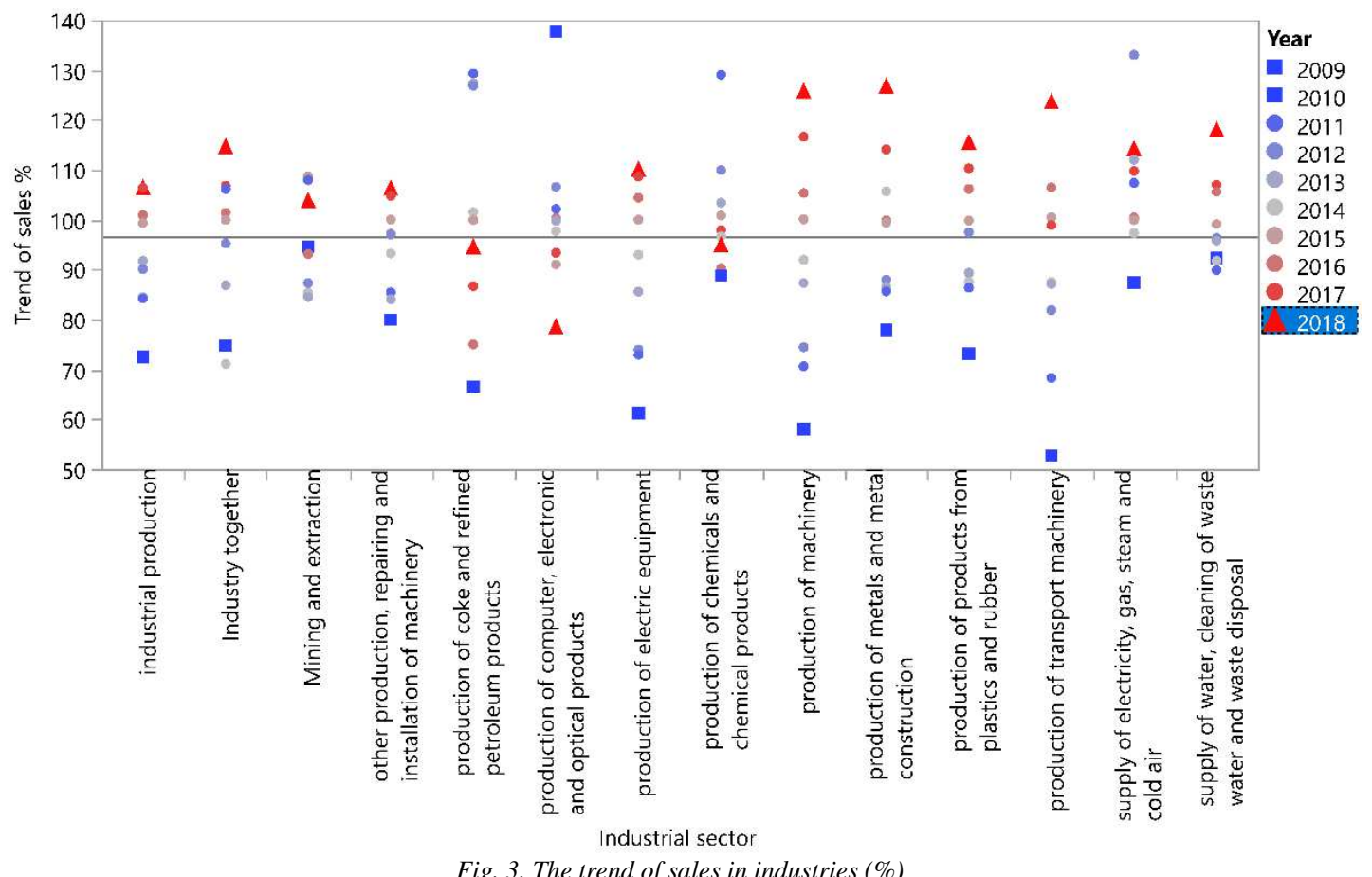

These results are complemented by Figure 4, which expresses, through linear regression, the long-term direction of individual industries. Based on the results of the linear regression, sectors with a declining development trend for the observed period were defined; this group includes the following sectors:

-production of coke and refined petroleum products,

- production of computer, electronic and optical products,

- production of chemicals and chemical products.

On the other hand, sectors with long-term growth were defined, the $\mathrm{R}^{2}$ indicator also assesses the stability of the trend defined - higher $\mathrm{R}^{2}$ values represent a more stable development. Long-term growing industries include:

- industrial production,

- other production, repairing, and installation of machinery,

- production of electrical equipment,

- production of machinery,

- production of metals and metal construction,

- production of products from plastics and rubber,

- production of transport machinery. 


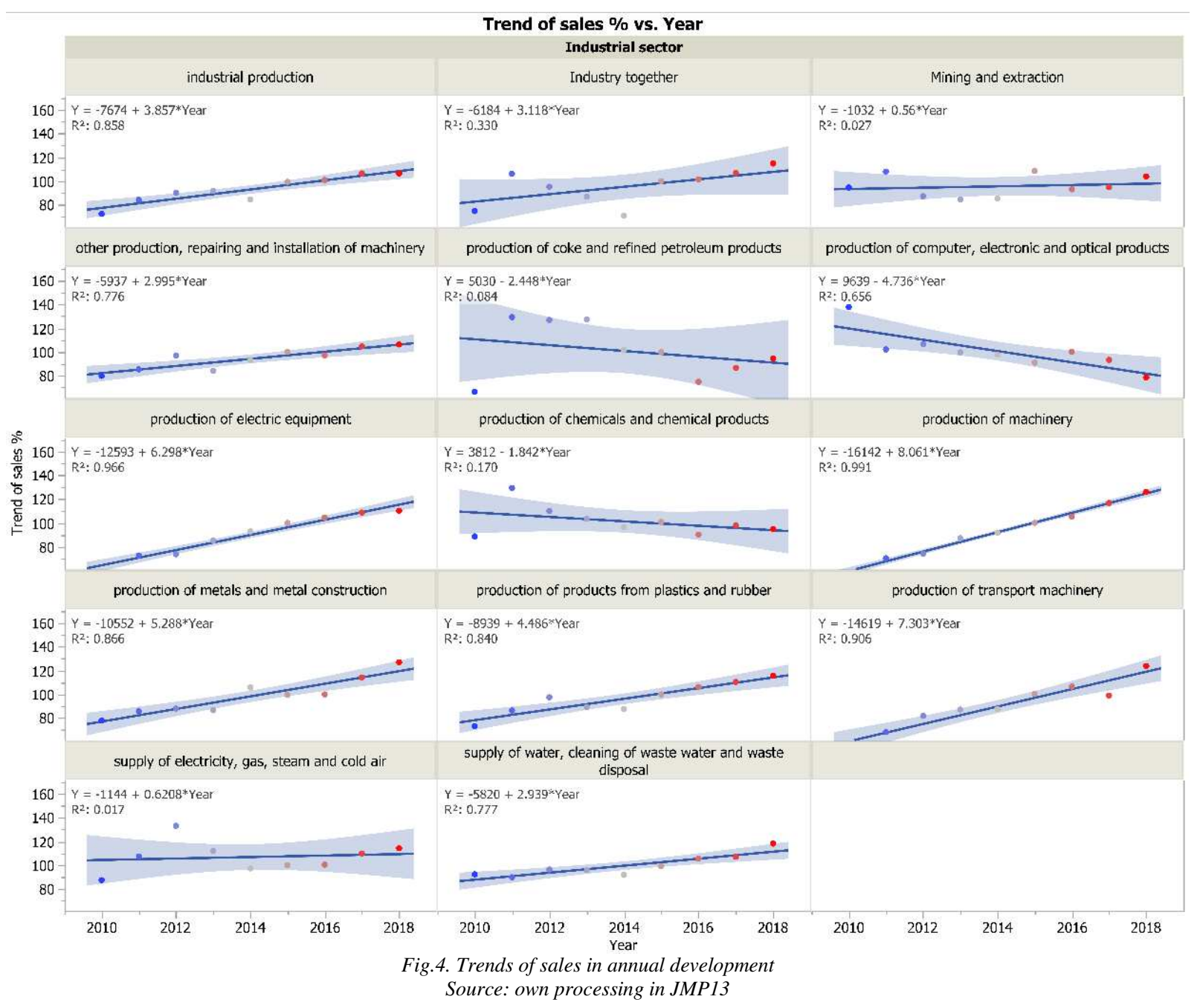

The following facts clearly emerged from the graphical representation of the growth rate of the analyzed industries in 2018 (Fig. 5):

- the highest growth rate was recorded in the production of metals and metal construction, while the second-highest rate was in the production of machinery and the third rate in the production of transport machinery,

- on the other hand, the production of computer, electronic and optical products had the lowest rate, while the production of coke and refined petroleum products had the second-lowest rate and the production of chemicals and chemical products the third-lowest rate,

- the growth rate of mining and extraction showed the highest level in the year under review.

Those (growing) sectors presently represent sectors with the highest potential of mining inputs using. As mentioned, an increasing trend in some cases is defined by a low value of determination index, which means certain instability, for example, Industry together with value $R^{2}=0,33$. 


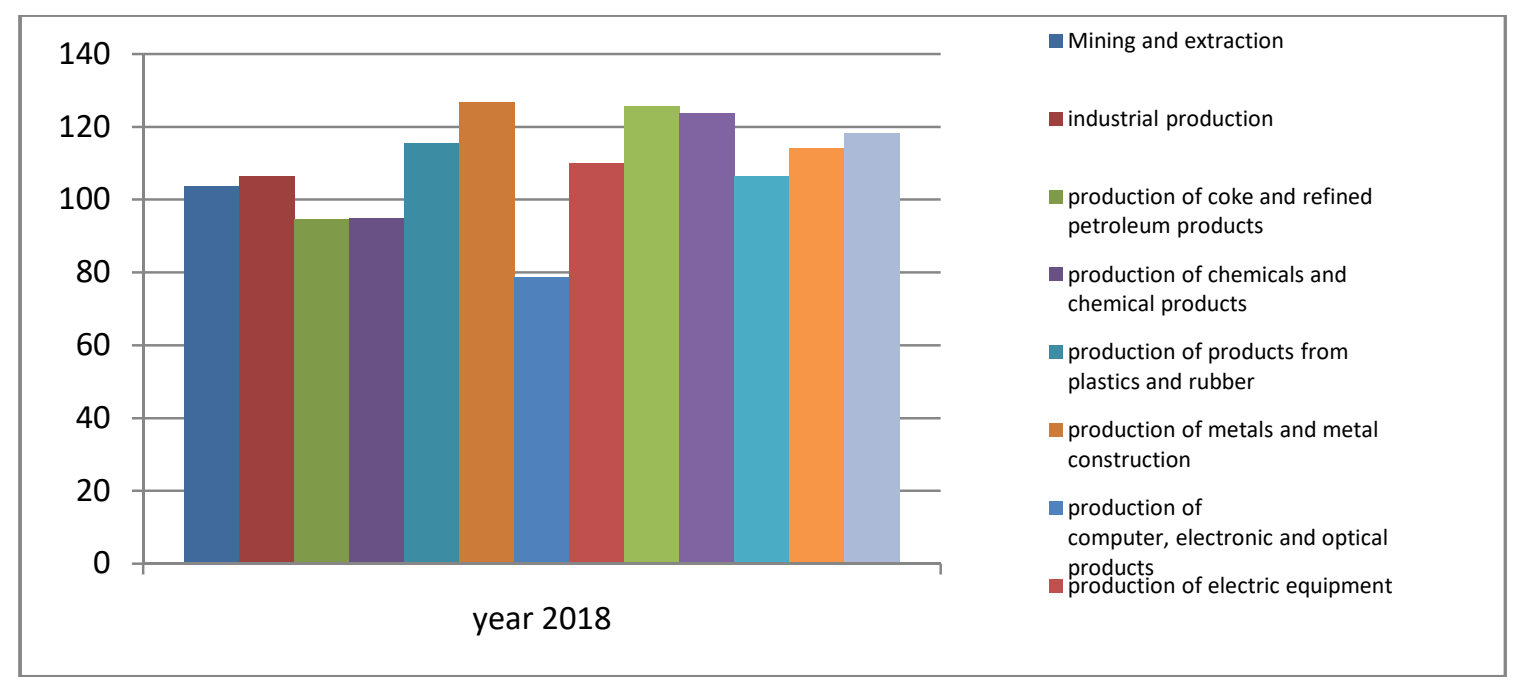

Fig.5. The growth rate of industries in 2018

Source: own processing according to data ( $w w w 2)$

On the one hand, the future of the mining sector can be defined by the demand for raw materials from sectors with stable development, on the other hand by estimation of future development of the national economy. One of the methods predicting the future orientation of the business sector is an analysis of keywords, which helped define the future needs of the society. The results of the analysis of the keyword are presented by bubble graph, illustrated in Figure 6. The volume of the bubble presents a multiplicity of the given term (keywords) finding.

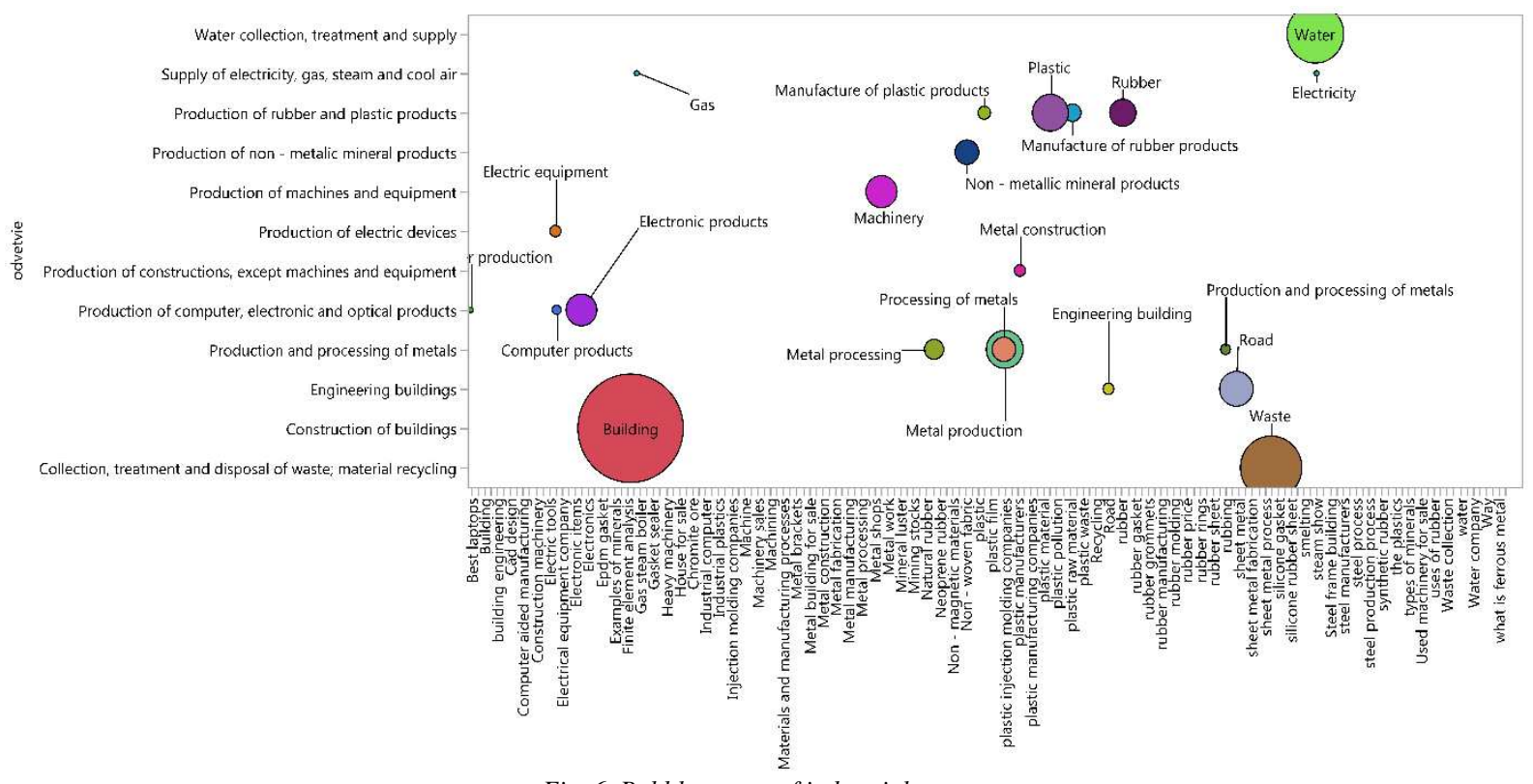

Fig. 6. Bubblegroups of industrial sectors Source: own processing

According to the bubble analysis, we found the most findings connect with the key term "building", which belong to the sector Construction of buildings, further with key term "waste", which belong to the sector Collection, treatment and disposal of waste, material recycling and also with the key term "water", which belongs to the sector Water collection, treatment, and supply. Based on the analysis of bubble groups of industrial sectors, it is also possible to state that the least frequent finding is the key term "gas", which belong to the sector Supply of electricity, gas, steam and cool air, further with key term "computer products", which belongs to the sector Production of computer, electronic and optical products, further with key term "electric equipment", which belongs to the sector Production of electric devices.

Given the explicit findings from the detailed bubble analysis, it can be stated that the given sector Construction of buildings should be the subject of further analysis of interaction relations with the emphasis on non-hazardous raw materials and secondary raw materials. 


\section{Discussions and Conclusion}

Mining and metallurgy present one of the important sectors in some countries. It has its strategic importance and plays a pivotal role in influencing the economy of the country (Karthick and Kasthuri, 2015). The mining industry is closely connected with other industrial sectors, especially metallurgy. Mining and metallurgical companies have an irreplaceable task in the country's economy - in the creation of working posts, the flexibility of the market mechanism, and the creation of the added value. Both industries are very similar, for example, due to the generation of residues (Cruz-Hernández et al., 2018). During the recent economic crisis and the recovery period, there is a need to study the position of the companies that contribute to economic growth. Many studies attempted to understand the contribution of individual sectors to the state economy (for example, Manova et al., 2018). Due to the globalization process, there is a need to study also international competitiveness of the mining sectors and industries, measuring position in the global value chains ( $\mathrm{Su}$ et al., 2020). According to Commendatore et al. (2020), the industry's growth is influenced by regions of their activity, when the trade has a substantial impact on industry location and trade patterns affect strongly level of integration of industries and regions. This is supported by Ranestad's (2020) study, dealing with strong networks created between multinational mining companies and local industries.

Presented contribution evaluates the interdependence of the mining industry in connection to other sectors. The strongest dependence is found in the Construction and Buildings sector. Providing sustainable economic growth is conditioned by a reliable supply of raw materials and energies with optimal costs and proper protection of the living environment. European Union presently disposes of the most open and most integrated unique market with electricity and gas. The majority of developed countries recognized that the market in energetics was the most important task during the last decades. Together with the collapse of centrally planned economies, the trend of liberalization became global - influencing transitive economies' policy in developing countries and international businesses. The dependence of the EU on the import of some strategic raw materials from unstable regions threatens its security. Therefore, it is very necessary to deal with the task of raw materials using in industries not only by research institutions but also by all interested stakeholders.

The research was orientated on the connection between the mining industry's influence on other industrial sectors from the view of sales and employment growth rate. The results of the study are useful for the determination of mining industry development, and future research can be extended to other macro-economic indicators, influencing the competitiveness of the sectors.

\section{References}

Alhajji, A. (2007). What is energy security? General/Supply/Demand. Oil, Gas \& Energy LawOGEL 4 (2007). Retrieved August 20, 2019, from www.ogel.org/article.asp?key=2676

Anyakoha, C. (2018). Achieving sustainable development in Nigeria via innovative education. The role of business education. Acta Oeconomica Universitatis Selye, 7(1), 7 - 20.

Brent Crude Oil Prices - 10 Year Daily Chart. Retrieved January 1, 2019 from https://www.macrotrends.net/2480/brent-crude-oil-prices-10-year-daily-chart

Blišt’an, P., Kršák, B., Blišt’anová, M. and Ferencz, V. (2015). The seabed-an important mineral resource of Slovakia in the future. Acta Montanistica Slovaca. Vol. 20, no. 4 (2015), s. 334-341. ISSN 1335-1788

Cehlár, M., \& Maras, M. (2001). Economic evaluation of Mining Projects. Košice: TU, FBERG.

Ciruelos, J. and Duchene, M. (1983). Modele sur micro-ordinateur pour l'analyse de la faisabilite financiere d'un projet minier. Industrieminérale - Les techiniques.

Commendatore, P., Kubin, I., Sushko, I. (2020). Obtaining a hub position: A new economic geography analysis of industry location and trade network structures. Metroeconomica, DOI: 10.1111/meca.12314.

Cruz-Hernández, Y., Ruiz-García, M., Villalobos, M., Romero, F.M., Meza-Figueroa, D., Garrido, F., Hernández-Alvarez, D., Pi-Puig, T.(2018). Fractionation and mobility of thallium in areas impacted by mining-metallurgical activities: Identification of a water soluble TI (I) fraction. Environmental Pollution, 237, 154-165.

COFACE, Energy. (2018). Economic studies and country risks. Retrieved November 20, 2018 from http://www.coface.com/Economic-Studies-and-Country-Risks/Energy

Diabat A, Kanna D., \& Mathiyazhagan K. (2014).Analysis of enablers for implementation of sustainable supply chain management - A textile case. Journal of Cleaner Production, 83, 391-403.

Dul'ová Spišáková, E., Mura, L., Gontkovičová, B., \& Hajduová, Z. (2017). R \& D in the context of Europe 2020 in selected countries. Economic Computation and Economic Cybernetics Studies and Research, 51(4), $243-261$. 
Ferella, F., D’Adamo, I., Leone, S., Innocenzi, V., De Michelis, I., \& Veglió, F. (2019). Spent FCC E-Cat: Towards a circular approach in the oil refining industry. Sustainability (Switzerland), 11(1), 113.

Ishchenko, M. (2013). Mining and beneficiation companies' liabilities figures correction. Economic Annals-XXI, 11-12(1), 58 - 61.

Ivanova, M., Varyanichenko, O., Sannikova, S., \&Faizova, S. (2018). Assessment of the competitiveness of enterprises. Economic Annals - XXI, 173(9-10), 26-31.

Jokar, Z., \& Mokhtar, A. (2018). Policy making in the cement industry for CO2 mitigation on the pathway of sustainable development - A system Dynamics approach. Journal of Cleaner Production, 201, 142-155.

Karthick, C., Kasthuri, P. (2015). A study on financial performance of Hindustan petroleum corporation limited. Journal of Interdisciplinary and Multidisciplinary Research, 2(5), 109-112.

Katare, V.D., \& Madurwar, M.V. (2020). Design and investigation of sustainable pozzolanic material. Journal of Cleaner Production, 242, 118431.

Kot, S., \& Macris, M. (2014). Systemic Approaches to Strategic Management: Examples from the Automotive Industry. IGI Global, 50 - 63.

Liang, X., Ye, M., Yang, L., Fu, \& W., Li, Z. (2018). Evaluation and policy research on the sustainable development of China's rare earth resources. Sustainability (Switzerland), 10(10), 3792.

Lopes, L., Miklovicz, T., Bakker, E., \& Milosevic, Z. (2018). The benefits and challenges of robotics in the mineral raw materials sector - An overview. IEEE International Conference on Intelligent Robots and Systems, 8594218, 1507-1512.

Mačanga, M. (2014). Energetic security of regions: theoretical-methodological base, measurement and evaluation (in Slovak). Retrieved June $30, \quad 2019$ from https://www.siea.sk/materials/files/poradenstvo/aktuality/2014/energofutura/Macanga_Energeticka_bezpe cnost_regionov_SIEA_Energofutura_2014.pdf

Manová, E., Čulková, K., Lukáč, J., Simonidesová, J., \& Kudlová, Z. (2018). Position of the Chosen Industrial Companies in Connection to the Mining. Acta Montanistica Slovaca, 23 (2), 132-140.

Marshall, J.A., Bonchis, A., Nebot, E., \& Scheding, S. (2016). Robotics in mining. Springer Handbook of Robotics, p. 1549-1576. Springer Verlag: Berlin.

Pacáková, V., Labudová, V., Sipková, L., Šoltés, E., \& Vojtková, M. (2009). Statistic methods for economists (in Slovak). Iura Edition: Bratislava.

Pačaiová, H., \& Blišt’an, P. (2010). Energetic industry and risk management (in Slovak). Kvalita Řízení. Retrieved 11 April, 2010 from http://katedry.fmmi.vsb.cz/639/qmag/mj77-cz.pdf

Ranestad, K. (2020). Multinational mining companies, employment and knowledge transfer: Chile and Norway from ca.1870 to 1940. Business History, 62(2), 197-221. DOI: 10.1080/00076791.2017.1407313.

Shetty, P.K., \& Raghavendra, K.C. (2018). A study of inventory management at manufacturing industries in rural India. International Journal of Mechanical and Production Engineering Research and Development, 9(1),73-80.

Slovak Republic in figures. (2007). Statistical Office of the Slovak Republic: Bratislava. Retrieved January 31, 2018 from https://slovak.statistics.sk/wps/portal/

Su, H.Y., Hou, F.M., Yang, Y.X., Han, Z., Liu, C. (2020). An assessment of the international competitiveness of China's forest products industry. Forest Policy and Economics, 119, 102256. DOI: 10.1016/j.forpol.2020.102256.

Šimák, L. (2006).Risk management (in Slovak). University of Žilina: Žilina.

Šimková, Z., Očenášová, M., Tudoš, D. \& Róth, B. (2019). The political frame of the European Union for mining of non-energetic raw materials. Acta Montanistica Slovaca, 24 (1), 35 - 43.

Zuberec, J., Tréger, M., Lexa, J., \& Baláž, P. (2005). Raw material of Slovakia. Bratislava: Štátny geologický ústav Dionýza Štúra.

www1: (http://app.kwfinder.com)

www2: http://datacube.statistics.sk/, Sector statistics. (2019). Retrieved May 12, 2019 from $\underline{\text { http://datacube.statistics.sk/ }}$ 